\title{
TUBUH KRISTUS: KORBAN, KARYA DAN PENGHARAPAN BAGI PELAYANAN DI BUMI BHINEKA TUNGGAL IKA
}

\author{
Mulyo Kadarmanto
}

\begin{abstract}
Abstrak: Tulisan ini bertujuan untuk menemukan kembali signifikansi makna tubuh Kristus baik yang telah dikerjakan, sedang dikerjakan dan yang akan datang. Dengan melihat makna tubuh Kristus pada masa lampau dan yang menjadi harapan di waktu yang akan datang, maka dapat ditemukan signifikansinya bagi permasalahan didalam tubuh Kristus (gereja) pada masa kini, terkhusus dalam pergumulan perpecahan gereja. Dengan penghayatan kembali makna tubuh Kristus, diharapkan dapat menjadi fondasi bagi kesatuan gereja untuk mewujudkan kesaksian sebagai murid-murid Yesus Kristus, yang secara utuh dalam keberagaman memiliki kesatuan hati demi pelayanan di bumi Bhineka Tunggal Ika.
\end{abstract}

Kata kunci: Tubuh Kristus, korban, keutuhan, keberagaman, perpecahan, pelayanan.

\section{PENDAHULUAN}

Data yang dirilis oleh Center for the Study of Global Christianity dari GordonConwell Theological Seminary tentang pertumbuhan denominasi kekristenan di dunia, ${ }^{1}$ ditemukan data sebagai berikut:

\begin{tabular}{|cc|}
\hline Tahun & Jumlah \\
\hline $\mathbf{1 9 0 0}$ & 1.600 denominasi \\
\hline $\mathbf{2 0 0 0}$ & 34.200 denominasi \\
\hline Mid-2015 & 45.000 denominasi \\
\hline
\end{tabular}

Tabel 1: Pertumbuhan Denominasi di Dunia

Jika kita memperhatikan data tersebut, maka ada peningkatan sekitar 32.600 sepanjang tahun 1900-2000, dengan rata-rata penambahan 326 denominasi

\footnotetext{
${ }^{1}$ http://www.gordonconwell.edu/resources/documents/IBMR2015.pdf; Internet; diakses 18 Februari 2015.
} 
pertahun. Berikutnya adalah lebih mengejutkan lagi, bahwa hanya dalam selang waktu 15 tahun (2000-2015) diperkirakan ada peningkatan sekitar 10.800 denominasi, dengan rata-rata peningkatan 720 denominasi per tahunnya.

Di Indonesia sendiri saat ini memiliki sekitar 300-an sinode gereja dan 192 sekolah teologi. ${ }^{2}$ Kita harus bersyukur untuk jumlah yang cukup besar dalam melaksanakan panggilan pelayanan di Indonesia, dengan kehadiran sinode gereja, sekolah teologi dan juga organisasi-organisasi pelayanan Kristen lainnya. Namun di sisi lain, ternyata angka tersebut justru menampilkan satu sisi keprihatinan sebagai tubuh Kristus. Tidak dapat dipungkiri bahwa tidak sedikit didalamnya merupakan hasil perpecahan dari gereja dan sekolah teologi lainnya. ${ }^{3}$ Tentunya produk perpecahan tersebut tidak dapat digeneralisir terhadap semua sinode, sekolah teologi atau organisasi-organisasi Kristen. Karena sebagian besar juga adalah buah dari pelayanan - yang karena perkembangan pemberitaan Injil - memiliki kekhasan panggilan pelayanannya masing-masing dan bukan sebagai hasil konflik (perpecahan). Secara positif, keberagaman denominasi dapat dilihat sebagai dinamika karya Allah yang menumbuhkembangkan gereja-Nya.

Perpecahan itu sendiri memiliki berbagai penyebab yang seringkali sangat jauh dengan perbedaan esensi kekristenan (doktrin primer); namun lebih banyak disebabkan oleh doktrin-doktrin sekunder, ${ }^{4}$ kepentingan individu, kepentingan kekuasaan, pertimbangan-pertimbangan manusiawi yang kesemuanya itu telah

${ }^{2}$ Data jumlah Sekolah Teologi tersebut berdasarkan data yang dirilis dalam website resmi Pendidikan Tinggi di www.forlap.dikti.go.id (diakses 1 April 2015). Tentunya angka tersebut belum termasuk sekolah teologi lainnya yang belum terdaftar resmi di Dikti, namun sudah terdaftar di Kementerian Agama Bimas Kristen. Itu berarti jumlah STT di Indonesia lebih banyak dari angka tersebut.

${ }^{3}$ Dalam artikel tersebut Daniel Lucas Lukito menyoroti pengenalan akan Allah sebagai testing ground manusia. Di akhir penulisannya beliau berusaha menarik aplikasinya dalam dunia pelayanan Kristen, baik dalam lingkup gereja, STT atau organisasi Kristen lainnya. Keprihatinan akan perpecahan yang terjadi dalam pelayanan Kristen, yang banyak disebabkan oleh sikap arogansi, prestasi, kekuasaan dan lain-lain; yang menjadi sumber memalukan bagi kesaksian gereja yang dikatakan telah memiliki pengetahuan akan Allah. http://www.seabs.ac.id/journal/april2009/500\%20Tahun\%20Yohanes\%20Calvin.pdf; Internet; diakses 18 Februari 2015.

${ }^{4}$ Jan S. Aritonang sebagai profesor sejarah gereja di Indonesia, memberikan pengamatannya bahwa pertikaian dan perpecahan sering terjadi di Indonesia yang disebabkan kemajemukan pemahaman, secara khusus Aritonang menyorotinya untuk gereja-gereja yang ada di dalam gerakan Injili di Indonesia. Lih. Jan S. Aritonang, Berbagai Aliran di Dalam dan Sekitar Gereja (Jakarta: BPK Gunung Mulia, 2005), 256. 
dikemas dengan kepalsuan dan memanipulasinya sebagai visi dari Allah dan dasar palsu yang "dialkitabiahkan". Sungguh, kondisi perpecahan itu merupakan kenyataan yang menyedihkan ${ }^{5}$ dan gereja mengalami kerugian terbesar, ${ }^{6}$ demikian komentar John Stott sebagai teolog injili.

Jika menilik konteks pelayanan masa kini dan panggilan untuk bersaksi di masa-masa ini, akan terlihat beberapa hal yang dapat menjadi kecenderungan perpecahan. Dengan alasan adanya visi yang berbeda -padahal dulunya sevisihingga pada "haus" kekuasaan dalam dunia pelayanan. ${ }^{7}$ Perpecahan-perpecahan tersebut sangat memprihatinkan dan dapat menimbulkan kesaksian yang tidak baik bahkan menjadi batu sandungan bagi dunia pelayanan. Hal ini juga yang menjadi pengamatan dari Tahalele dan Santoso, bahwa dalam kehidupan sesama anggota tubuh Kristus sendiri terpecah belah dalam beberapa denominasi dan tidak bersatu dalam kesatuan visi dan misi. ${ }^{8}$

'Perpecahan' sebenarnya merupakan istilah yang kurang nyaman untuk didengar dan dipergunakan, terlebih untuk gereja atau lembaga-lembaga gerejawi sebagai tubuh Kristus. Istilah ini seringkali melekat dan dilabelkan secara khusus untuk gerakan injili. ${ }^{9}$ Perpecahan dalam gereja dan lembaga-lembaga gerejawi, telah mereduksi tanggung jawab untuk memberitakan tubuh Kristus dalam kondisi-kondisi terkini dalam konteks dimana gereja berada. Perpecahan terus menerus menciderai bukti keberimanan akan pengorbanan tubuh Yesus Kristus. Berdasarkan fenomena-fenomena tersebut, penulis ingin membahas kembali karya-karya pengorbanan Yesus Kristus yang menjadi fondasi untuk "tubuh Kristus" berkarya di waktu kekinian. Karya pendamaian yang telah dikerjakan oleh Satu orang untuk keberlangsungan hidup umat pilihan-Nya di masa sekarang dan masa yang akan datang. Penulis akan melihat tubuh Kristus dalam ketiga aspek studi yang sangat saling berkaitan, yang bertumpu pada pribadi Yesus Kristus, yaitu dari aspek kristologis, ekklesiologis dan eskatologis. Pada akhirnya

\footnotetext{
${ }^{5}$ Lih. Yahya Wijaya, Meniti Kalam Kerukunan (Jakarta: BPK Gunung Mulia, 2007), 469.

${ }^{6}$ John stott, The Living Church (Jakarta: BPK Gunung Mulia, 2007), 162.

${ }^{7}$ Lih. Louis Berkhof, Teologi Sistematika 5: Doktrin Gereja (Jakarta: Lembaga Reformed Injili Indonesia, 1997), 60.

${ }^{8}$ Mengutip Tahalele dan Santoso dalam Jan. S. Aritonang, Sejarah Perjumpaan Kristen dan Islam di Indonesia (Jakarta: BPK Gunung Mulia, 2004), 479.

${ }^{9}$ Jan S. Aritonang, Berbagai Aliran di Dalam dan Sekitar Gereja, 256.
} 
penulis akan melihat signifikansinya dalam pelayanan gereja di Indonesia masa kini.

\section{MAKNA TUBUH KRISTUS: KORBAN, KARYA DAN PENGHARAPAN}

\section{Tubuh Kristus Sebagai Korban}

Dalam terang Perjanjian Baru, korban di dalam Perjanjian Lama dilihat sebagai tipologi dari pengorbanan Yesus Kristus di kayu salib. Nubuatan Allah akan tubuh Kristus sebagai korban sejati yang berlaku secara terus menerus dan bersifat permanen sudah dijanjikan Allah dalam Perjanjian Lama. Allah sendiri telah berinisiatif memulai peristiwa korban untuk menutupi keberdosaan manusia, supaya manusia tidak mati dan malu dengan ketelanjangannya (bdk. Kej. 3:21). Peristiwa ini adalah penumpahan darah pertama kali yang dicatat oleh Kitab Suci, akibat kejatuhan manusia dalam dosa, yang kemudian dilanjutkan dengan upacara persembahan korban yang telah diatur dan dilembagakan dalam kehidupan umat Allah selanjutnya. Secara keseluruhan, pada akhirnya Allah juga yang harus bertindak untuk menutupi ketelanjangan akan keberdosaan manusia, dan didalam pengorbanan Yesus Kristus yang telah disediakan dan diutus oleh Allah, dosa manusia ditutupi (ditebus).

Jika kita mengingat kembali persembahan korban dalam konteks Perjanjian Lama, maka hal itu merupakan upacara yang tidak bisa tidak dilakukan oleh para imam dan umat Allah. Imam dari keluarga Harun yang telah ditunjuk oleh Allah berlaku sebagai pengantara untuk menghantarkan persembahan korban tersebut. Dengan bertindak sebagai pengantara, maka para imam sendiri harus memberikan korban pendamaian untuk dirinya sendiri sebelum menunaikan tugas keimamannya. Dengan demikian mereka dilayakkan untuk berdiri dihadapan Allah mewakili umat Allah. Mereka menyajikan persembahan korban yang dilakukan tiap-tiap hari untuk tetap memelihara perdamaian dengan Allah, sehingga diperkenankan memasuki persekutuan dengan Allah. Korban persembahan yang diperintahkan Allah merupakan bayangan akan hadirnya korban yang sejati dan kekal. Melalui 
korban persembahan, umat dipersiapkan dan disadarkan hingga kedatangan korban yang sempurna sebagai klimaks dari sejarah keselamatan

Korban-korban yang dapat dibawa kepada Allah telah diatur sedemikian rupa dan korban yang dipersembahkan haruslah kepunyaan sendiri. Untuk itu, Tuhan memberikan alternatif bentuk korban bagi orang-orang yang tidak mampu. Dalam persembahan korban, umumnya harus mencurahkan darah, karena darah dilihat sebagai tanda kehidupan. Darah disimbolkan sebagai penyuci atas segala kesalahan yang dilakukan manusia. Korban pengganti yang disimbolkan dalam Perjanjian Lama menegaskan bahwa segala dosa umat ditimpakan pada binatang korban, sebagai korban pengganti. Inilah yang dijelaskan oleh Louis Berkhof bahwa dalam Perjanjian Lama, korban memiliki natur tipiko-profetis, dimana korban tersebut selain bersifat seremonial dan simbolis, juga bersifat spiritual dan tipikal. ${ }^{10}$ Korban yang dibawa mendekat ke rumah Tuhan bertujuan agar Tuhan berkenan akan umat (Im. 1:3), karena pada umumnya persembahan korban dilaksanakan dengan tujuan untuk memelihara kedekatan atau relasi antara Allah dan umat, yaitu dengan adanya pendamaian.

Korban dalam Perjanjian Lama dan korban dalam Perjanjian Baru memiliki esensi pengorbanan yang sangat prinsipil, yaitu pencurahan darah. Namun pencurahan darah tidak akan terjadi jika tanpa disertai dengan pengorbanan tubuh, mengingat satu kehidupan hanya terjadi dalam keberadaan kesatuan tubuh dan darah. Tubuh dan darah inilah yang juga merupakan kesatuan kehidupan dalam diri manusia Yesus, yang disebut dalam kitab Ibrani sebagai Korban yang sempurna, yang dipersembahkan satu kali, dan berlaku untuk selama-lamanya dalam melakukan karya penebusan dan pengudusan (Ibr. 10:10). Pengorbanan adalah tindakan yang berlaku persis dalam apa yang tertulis dalam Perjanjian Lama, dalam hal esensi korban tersebut dan bukan pada tata cara mengorbankannya. Dalam Perjanjian Lama, Allah telah mengatur tata cara penyembelihan korban dan pemotongan hingga meletakkan korban itu di hadapan Allah; dalam hal inilah dengan jelas memperlihatkan bahwa persembahan korban, mutlak adanya

${ }^{10}$ Louis Berkhof, Teologi Sistematika 3: Doktrin Kristus, terj. (Jakarta: Lembaga Reformed Injili Indonesia, 1997), 141. 
pencurahan darah. Diakhir pembahasannya tentang makna darah, A. M. Stibbs menyimpulkan demikian:

Now, let us seek to sum up more generally and more comprehensively the main significance of the word 'blood' as we have seen it to be used throughout the whole Bible. Blood is a visible token of life violently ended; it is a sign of life either given or taken in death. Such giving or taking of life is in this world the extreme, both of gift or price and of crime or penalty. ${ }^{11}$

Apa yang dikatakan Stibbs ingin menegaskan juga bahwa darah yang adalah nyawa, mendemonstrasikan bahwa pengorbanan tubuh dan darah adalah pemberian nyawa, kehidupan. Korban yang sempurna dalam diri Yesus berbicara akan pengorbanan tubuh yang memuat keniscayaan bahwa darah juga akan tercurah. Demikian juga yang disampaikan oleh Leon Morris, seorang teolog biblika injili bahwa "that in both the old and new testaments the blood signifies essentially the death. It is freely admitted that there are some passages in which it is possible to interpret the blood as signifying life, but even these yield a better sense (and one which is consistent with the wider biblical usage) if understood to mean "life given up in death". ${ }^{12}$

Yesus Kristus sebagai Anak Domba Allah telah memasuki Ruang Mahakudus layaknya para imam pada umumnya, namun Ia tidak membawa darah domba jantan atau anak lembu, tetapi Ia membawa darah-Nya sendiri (Ibr. 9:1). Selanjutnya penulis Ibrani juga menyatakan bahwa, “...hampir segala sesuatu disucikan dengan darah; dan dosa hanya bisa diampuni kalau ada penumpahan darah" (Ibr. 9:22). Inilah yang diurutkan oleh Grudem bahwa tubuh dan darah-Nya adalah sebagai pengorbanan, pendamaian, rekonsiliasi dan penebusan. ${ }^{13}$

Kitab Ibrani memaparkan dengan lebih jelas akan makna pengorbanan Yesus Kristus, dimana Ia sebagai Anak Domba Allah, telah memberikan korban yang sempurna dan bertindak juga secara langsung sebagai Imam. Dalam hal ini, John Stott memberikan penekanan dalam istilahnya sebagai superioritas

\footnotetext{
${ }^{11}$ A.M. Stibbs, The Meaning of The Word 'Blood' in Scripture (London: The Tyndale Press, 1962), 30.

${ }^{12}$ Leon Morris, The Apostolic Preaching of the Cross (Grand Rapids: W. M. B. Eerdmans Publishing Co., 2000), 126.

${ }^{13}$ Wayne Grudem, Systematic Theology: An Introduction to Biblical Doctrine (Nottingham: InterVarsity Press, 1994), 580.
} 
keimaman Kristus. John Stott menguraikan bahwa penulis Ibrani memiliki tema besar yaitu superioritas keimaman Kristus, dimana Yesus terus menerus dan tetap memegang keimaman-Nya sebab Dia hidup selama-lamanya. Superioritas pengorbanan-Nya dinyatakan dalam diri-Nya, dimana Ia sendiri mempersembahkan darah-Nya, yakni diri-Nya sendiri. Dia korban sekaligus imam, inilah superioritas pengorbanan Yesus Kristus. Hal ini menyatakan bahwa penulis Ibrani menunjukkan penggenapan bayangan yang tidak sempurna dari ritual Perjanjian Lama di dalam diri Kristus. ${ }^{14}$ Selain superioritas keimaman dan pengorbanan Kristus, John Stott juga melihat superioritas terakhir yaitu kovenan Allah. Dimana Imam dan korban yang unik, telah membangun kovenan yang unik, sesuai yang tertulis di dalam Yer. 31-31-34. ${ }^{15}$

Dalam superioritas keimaman-Nya itulah Yesus Kristus dapat bertindak dengan sempurna untuk menerima hukuman pengganti. Ia bertindak sebagai pengganti atau wakil atas umat yang berdosa. Dalam hal ini Wayne Grudem menjelaskan bahwa, "A vicar is someone who stands in the place of another or who represents another. Christ's death was therefore 'vicarious' because he stood in our place and represented us". ${ }^{16}$ Imam dan Yesus berdiri sebagai vicar mewakili umat-Nya berdiri dihadapan Allah. Melalui pengorbanan-Nya tercapai penebusan dan pendamaian. Berbicara sebagai korban pengganti, maka kemanusiaan sejati dalam tubuh Yesus Kristus adalah sebagai suatu keniscayaan untuk pendamaian. ${ }^{17}$

Dengan demikian, tubuh Kristus sebagai korban juga menyatakan bahwa darah-Nya tercurah dalam karya pendamaian manusia dengan Allah. Pendamaian di dalam Kristus telah menyatukan orang percaya dan Allah. Kesatuan yang hanya dapat terjadi oleh satu pendamaian oleh darah Yesus Kristus. Yang dipersatukan dengan tubuh Kristus dan menjadi milik-Nya (Rm. 7:4). Pengorbanan itulah yang menciptakan rekonsiliasi. Ajith Fernando menjelaskan tentang kata rekonsiliasi yang berasal dari kehidupan keluarga

\footnotetext{
${ }^{14}$ John Stott, Kristus Yang Tiada Tara, terj. (Surabaya: Momentum Christian Literature, 2007), 64-65.

${ }^{15}$ Ibid., 66.

${ }^{16}$ Wayne Grudem, Systematic Theology, 579.

${ }^{17}$ Ibid., 540.
} 
dan persahabatan. Dari tindakan rekonsiliasi inilah kata "atonement" (pendamaian) berasal, yang berarti kita telah dijadikan "satu" (at one) dengan Allah (at-one-ment). ${ }^{18}$ Sebagai Imam dan korban yang sempurna, Ia bertindak sebagai Pengantara, yang mendamaikan dan menciptakan kesatuan dalam relasi Allah dan umat-Nya. Pendamaian sebagai hasil dari pengorbanan-Nya telah membuka pintu bagi tiap-tiap pribadi yang terpilih untuk menerima janji penebusan dalam karya penyelamatan Allah dan menikmati kesatuan sebagai umat Allah.

\section{Tubuh Kristus sebagai Karya Pengorbanan}

Karya pendamaian yang telah dikerjakan didalam korban tubuh Yesus Kristus, telah menghasilkan karya yang agung, karya yang menggenapi janji Allah (Kej. 3:15; Yer. 31:33; Mat. 1:21). Pengorbanan adalah cara yang harus ditempuh dan persekutuan atau kesatuan adalah hasil dari pendamaian tersebut. Dalam perspektif ekklesiologis, karya penebusan itulah yang telah melahirkan gereja, sebagai wujud real dan penggenapan janji dari karya pengorbanan tubuh Kristus di atas kayu salib. Sesuai dengan tujuan Yesus datang adalah untuk menyelamatkan umat-Nya dari dosa mereka. Hal ini menunjukkan bahwa ada umat milik kepunyaan-Nya yang menggenapi perjanjian Allah dalam Perjanjian Lama, bahwa dalam Perjanjian Baru yang dibangun-Nya, umat tertentu akan menjadi umat-Nya. Menunjuk komunitas yang telah ditebus dengan tubuh dan darah Yesus, Paulus menyebutnya sebagai tubuh Kristus, dan yang diistilahkan oleh Ajith Fernando sebagai umat manusia yang baru. ${ }^{19}$ Apa yang telah dikerjakan oleh Yesus Kristus melalui tubuh-Nya sebagai korban, maka itu adalah cikal bakal yang membentuk kelahiran umat-Nya.

Stanley J. Grenz menjelaskan keterhubungan penebusan karya Yesus Kristus dengan keberadaan persekutuan orang percaya sebagai communion sanctorum, yang disebut Grenz sebagai komunitas eskatologis, yang merupakan

\footnotetext{
${ }^{18}$ Ajith Fernando, Supremasi Kristus, terj. (Surabaya: Penerbit Momentum, 2006), 128, 129.

${ }^{19}$ Ibid., 183.
} 
istilah lain untuk tubuh Kristus. Menurutnya, Yesus adalah Revealer, Effector dan Originator dari komunitas eskatologis. ${ }^{20}$ Dalam melihat sebagai Revealer, Grenz melihat bahwa Yesus Kristus di dalam kemanusiaan dan keilahian-Nya sudah menyatakan akan Allah sendiri yang ada dalam persekutuan yang kekal sebagai komunitas Tritunggal dan Dia telah menyingkapkan tujuan Allah bagi keberadaan manusia yaitu hidup dalam komunitas (Revealer of life-in-community). ${ }^{21}$ Selanjutnya sebagai Effector, Grenz melihat bahwa hanya melalui Kristus yang memungkinkan terbukanya jalan bagi partisipasi orang percaya dalam persekutuan yang sejati. Dalam karya-Nya, Ia telah menyatakan peran melalui hidup dan pengajaran-Nya. Dia adalah Effector bagi komunitas Allah. Melalui kematian-Nya di atas kayu salib, Ia sudah membayar harga untuk mentransformasi orang percaya, sehingga memungkinkan untuk berpartisipasi dalam persekutuan komunitas Ilahi. Poin terakhir Grenz melihat Yesus Sebagai Originator, dimana Tuhan berdiri dalam permulaan dari persekutuan manusia baru, membentuk fondasinya dan menjadi sumber asalnya. Kelompok baru yang telah ditegakkan oleh Yesus adalah gereja, yang merupakan pioneer dari komunitas eskatologis. Dia akan datang kembali untuk menggenapi peran-Nya sebagai Originator. Dari ketiga istilah yang digunakan Stanley J. Grenz terlihat bahwa ketiga fungsi tersebut berbicara karya salib dalam pembentukan komunitas eskatologis yang adalah tubuh Kristus (gereja).

Paulus menggunakan istilah Tubuh Kristus sebagai metafora yang digunakan untuk menyebut persekutuan orang percaya yang telah dipanggil dalam terang-Nya yang ajaib, menjadi imamat rajani. Jika diperhatikan metafora ini dalam tulisan-tulisan Paulus, maka ada dua penjelasan dalam menunjuk metafora ini, yaitu di dalam 1 Kor. 12 dan Ef. 1:22-23, 4:5-16; Kol. 2:19. Dalam bagian pertama, yaitu 1 Kor. 12, Paulus menggunakan keseluruhan tubuh (the whole body), dimana seluruh tubuh mencakup seluruh organ dan bagian tubuh; telinga, mata, tangan, kaki. Seluruh keberadaan manusia dilihat sebagai anggota-anggota tubuh, yang merujuk bahwa orang percaya sebagai anggota-anggota tubuh Kristus yang menyatu dalam

\footnotetext{
${ }^{20}$ Stanley J. Grenz, Theology For The Community Of God (Grand Rapids: William B. Eerdmans Pub. Co., 1994), 350-52.

${ }^{21}$ Ibid., 350.
} 
eksistensi manusia. Yesus Kristus sendiri dilihat sebagai Tuhan, yang berada di luar tubuh, sebagai objek dari seluruh pelayanan dan penyembahan gereja-Nya. Dalam Ef. 1:22-23, 4:15-16 dan Kol. 2:19 Paulus menggunakan metafora bahwa Kristus adalah kepala, dan gereja adalah tubuh yang terpisah dalam pembagian organ tubuh tetapi menyatu secara organik. Dalam melihat kedua metafora ini, Wayne Grudem melihat keperbedaan ini mengingatkan bahwa dalam metafora itu kita jangan terlalu ekslusif atas satu metafora dan melupakan Kristus sebagai Tuhan yang memerintah di surga dan dibumi. ${ }^{22}$

Pengakuan akan Kristus sebagai Kepala Gereja, menunjukkan bahwa setiap anggota gereja memiliki satu ikatan Roh yang satu, terikat dan menyatu dalam kehidupan yang satu; yang tidak akan pernah dapat hidup dalam keterpisahan (tanpa keterhubungan) satu dengan lainnya. Kesatuan yang memungkinkan kehidupan dan semua organ tubuh dapat bekerja dan berelasi satu dengan lainnya, tanpa darah hanya kematian pada sistem kerja dan organ-organ tubuh yang akan terjadi. Didalam 1 Kor. 12, Paulus dengan jelas melihat bagian-bagian dari anggota tubuh, ia menyebutkan diantaranya telinga, mata, kaki dan tangan, semuanya ditempatkan dengan posisi yang berbeda dan memiliki fungsi yang juga berbeda-beda. Dalam konteks surat Paulus kepada jemaat di Korintus ini, kita dapat dengan jelas memahami bahwa Paulus sedang berbicara kepada jemaat lokal, persekutuan orang percaya yang ada di Korintus. Dalam konteks lokal tersebut, jemaat itu adalah tubuh Kristus, dan setiap individu adalah anggota tersebut. Setiap anggota memiliki karunia masing-masing sebagai tubuh Kristus dalam jemaat Korintus.

Jika kita memperhatikan bagian-bagian surat Paulus lainnya, maka kita juga menemukan fakta bahwa jemaat yang ada di Galatia, satu di dalam Kristus (Gal. 3:28). Jemaat di Efesus dikatakan sebagai kawan sewarga dari orang-orang kudus dan anggota-anggota keluarga Allah (Ef. 2:19), sedangkan jemaat Yerusalem dikatakan sebagai orang-orang kudus (Ro. 15:15). Atas dasar itu, jemaat di Makedonia dan Akhaya memberikan persembahan untuk jemaat di Yerusalem (Rm. 15:15-16). Melalui bagian ini, kita melihat bahwa

\footnotetext{
${ }^{22}$ Grudem, Systematic Theology, 858-59.
} 
setiap jemat-jemaat lokal sesungguhnya adalah juga bagian (anggota) tubuh Kristus bagi gereja yang am dan universal. Baik jemaat di Korintus, Makedonia, Akhaya, Kolose, Roma dll., semuanya adalah orang-orang kudus yang membentuk kumpulan-kumpulan yang berfungsi sebagai anggota-anggota tubuh Kristus secara universal. Dengan melihat bahwa setiap anggota dalam jemaat lokal memiliki karunia masing-masing, maka setiap jemaat lokal dalam gereja yang am dan universal juga memiliki karunia masing-masing. Semuanya -baik lokal maupun universal- memiliki karunia untuk digunakan dalam pembangunan tubuh Kristus. Stanley J. Grenz, menyatakan bahwa:

"as his "body", the church exists solely to do the will of Christ and in this way be his presence in the world. Like the human body, the church is also a unity made up of diversity (1 Cor. 12:1-31). Not all members have the same function, but all have the same goal; all are to be concerned for the others and to use their gifts in service to the whole". 23

Dengan demikian jelaslah bahwa karya pendamaian dari pengorbanan tubuh Kristus yang sudah menyatukan umat dan Allah, juga tidak lepas dari kesatuan di dalam umat itu sendiri sebagai komunitas yang didasarkan atas korban sempurna. Sebagai komunitas, orang percaya adalah anggota-anggota tubuh Kristus yang memiliki fungsi-fungsi berbeda, tetapi semuanya memiliki tujuan yang sama. Hal ini menekankan kesatuan yang berguna dalam fungsinya masing-masing untuk menuju kesatuan tujuan, yaitu pertumbuhan dan kedewasaan iman.

\section{Tubuh Kristus sebagai Pengharapan}

Kunci utama pengharapan dalam iman kekristenan, yaitu kebangkitan tubuh yang telah terjadi dalam Yesus Kristus dan pasti akan terjadi atas orang percaya. Kitab Suci dengan gamblang menegaskan bahwa orang percaya merupakan satu tubuh, diikat oleh Roh yang satu, dan memiliki satu pengharapan di dalam Dia (Ef. 4:4) Berasal dari Satu dan bertujuan kepada yang Satu. Yesus Kristus sebagai dasar pengharapan, sekaligus objek dari

\footnotetext{
${ }^{23}$ Grenz, Theology For The Community of God, 466-7.
} 
pengharapan orang percaya (1 Tim. 1:1). Dimana semua orang yang telah diselamatkan-Nya, mengarahkan pandangan kepada satu Pribadi, yaitu Yesus Kristus, Pengharapan Sejati.

Dalam menasehatkan jemaat di Korintus dengan seluruh kompleksitas permasalahan yang ada, Paulus mengisi bagian akhir dengan menekankan signifikansi kebangkitan tubuh Kristus. Kebangkitan tubuh Kristus adalah fondasi pengharapan orang percaya. Melalui teks 1 Kor. 15:32-34, Paulus menyampaikan tentang kebangkitan Yesus Kristus dan orang percaya. Bagian ini bukan hanya ingin meluruskan tentang pengajaran sesat yang mengatakan bahwa tidak ada kebangkitan orang mati, tetapi sangat berkaitan dengan bagian-bagian sebelumnya dimana jemaat di Korintus mengalami kebobrokan moral. "Jika orang mati tidak dibangkitkan, maka "marilah kita makan dan minum, sebab besok kita mati". Inilah pengaruh kecemaran yang membuat jemaat Korintus terbuai dan bergelimang kecemaran, hingga keretakan terjadi dalam jemaat. Paulus ingin menegaskan bahwa karena Kristus sudah bangkit, dan kita akan dibangkitkan, maka janganlah berbuat dosa lagi (1 Kor. 15:34). Baik dosa perpecahan, percabulan, perzinahan, penyembahan berhala, kemabukan dan pesta pora, dan jemaat Korintus dinasehatkan untuk menjaga pergaulan (bdk. 1 Kor. 15:23 dengan 1 Kor. 5:11). Paulus meminta agar jemaat Korintus berdiri teguh, tidak goyah dan giat dalam pekerjaan Tuhan. Hal ini didasarkan bahwa ada pengharapan kebangkitan, dan semua jerih payah itu tidak akan pernah sia-sia. Ini menampilkan signifikansi kebangkitan dalam bagian akhir dari surat 1 Korintus sebelum ditutup dengan nasehat-nasehat di pasal 16. Topik kebangkitan ini adalah sebagai puncak dari seruan Paulus sekaligus memulihkan pengharapan jemaat Korintus, untuk hidup didalam Injil seperti yang telah diberitakan dan diterima jemaat.

Peristiwa kebangkitan tubuh Kristus yang dimetaforakan oleh Paulus sebagai buah sulung (1 Kor. 15:23), merupakan satu metafora pertanian dan Wayne Grudem memahaminya bahwa ini adalah "an agricultural metaphor that likens Christ to the first sample of the harvest, showing what the other fruit from that harvest would be like". ${ }^{24}$ Sedangkan Hoekema menjelaskan kata

${ }^{24}$ Grudem, Systematic Theology, 542. 
"buah sulung" berarti hasil pertama dari tuaian, yang menjamin penggenapan akhirnya, sehingga kebangkitan Kristus adalah bukti dan jaminan bahwa kita yang ada didalam Kristus akan bangkit pula dari kematian (1 Kor. 15:20). Dalam Kol. 1:18, istilah "sulung" (prototokos) menyatakan sebagai yang sulung mengandung pengertian bahwa saudara-saudara-Nya akan pula bangkit dari kematian. ${ }^{25}$ Kesulungan ini menunjukkan bukti bahwa ada saudara-saudara-Nya. Selain itu, kebangkitan tubuh Yesus Kristus juga adalah prototype bagi kebangkitan orang percaya, menjadi model awal, yang dapat menjadi acuan bagi pengharapan kebangkitan. Kebangkitan sebagai tujuan dari tubuh Kristus dalam orang percaya, dimana umat Allah memiliki ekspektasi akan janji kehidupan dan penggenapannya. Kebangkitan itu sendiri menyatakan penegakan pemerintahan Allah, yang merupakan tujuan eskatologis dan tanda dalam pendirian komunitas Ilahi. ${ }^{26}$

Demikianlah makna tubuh Kristus yang dapat dilihat dalam perspektif kristologis, ekklesiologis dan eskatologis. Sesudah melihat makna tubuh Kristus, maka kita dapat melihat bagian diagram dibawah ini yang menunjukkan hubungan makna tubuh Kristus.

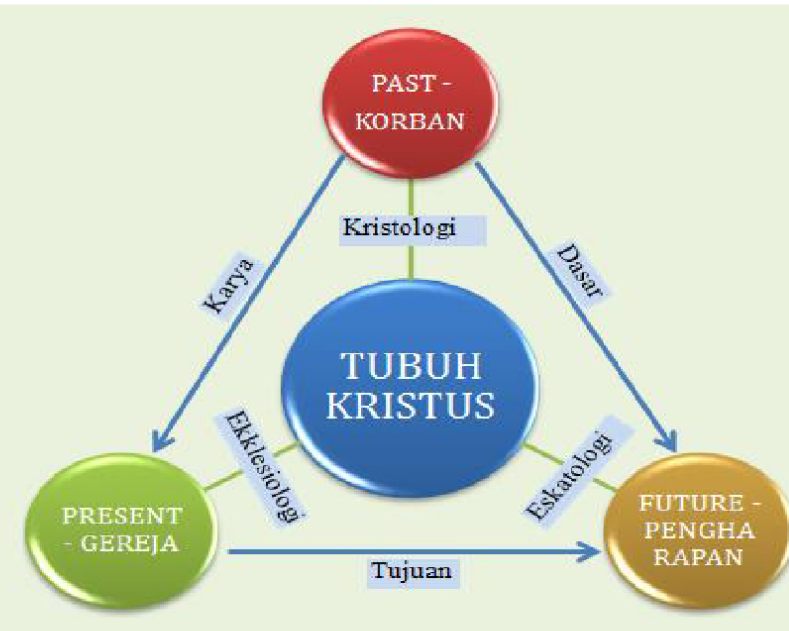

Bagan: Tubuh Kristus dalam studi teologi 333.

25 Anthony A. Hoekema, Alkitab dan Akhir Zaman (Surabaya: Penerbit Momentum, 2004),

26 Grenz, Theology For The Community of God, 260. 
Dalam studi kristologi kita melihat karya pengorbanan-Nya. Dalam studi ekklesiologi, kita dapat melihat karya pengorbanan Yesus yang menciptakan umat-Nya. Dan dalam studi eskatologi, orang percaya sebagai communio sanctorum memiliki pengharapan akan kebangkitan yang sama dengan didasarkan atas tubuh Yesus yang sudah dibangkitkan. Melalui pengorbanan satu orang, tubuh Kristus diselamatkan; melalui kebangkitan dan kemenangan satu orang, tubuh Kristus mendapatkan janji dan pengharapan; melalui karya satu orang, tubuh Kristus menjadi satu komunitas yang menerima satu tanggung jawab. Gereja sebagai tubuh Kristus "dibangun" oleh tubuh Yesus Kristus yang menekankan kesatuan dan ketiadaan perbedaan. Gereja sebagai tubuh Kristus memiliki pengharapan yang sama dan menekankan pengharapan bersama dengan Kristus. Dengan satu sumber hidup (korban Yesus Kristus) dan satu pengharapan (kebangkitan Yesus Kristus), sesungguhnya jemaat yang adalah tubuh Kristus memiliki panggilan untuk membangun kesatuan dalam memenuhi panggilan-Nya.

\section{SIGNIFIKANSI BAGI GEREJA-GEREJA SEBAGAI TUBUH KEKRISTENAN DALAM PELAYANAN DI BUMI BHINEKA TUNGGAL IKA}

Frasa "Bhineka Tunggal Ika" merupakan semboyan yang dikutip dari Kitab Sutasoma karangan Mpu Tantular sekitar abad ke-14, pada masa pemerintahan Majapahit. Istilah itu sendiri berasal dari bahasa Sansekerta, dimana "bhineka" berarti "beraneka ragam", "tunggal" berarti "satu", dan "ika" berarti "itu"; yang kemudian dimaknai dengan "berbeda-beda tapi tetap satu jua". Penting sekali makna ini dalam pembentukan negara Indonesia diawal kemerdekaan. Mengingat Indonesia adalah negara yang dilimpahi dengan kekayaan dan keanekaragaman suku, bahasa, dan budaya, semboyan ini menjadi pilar utama dalam menopang persatuan dan kesatuan sebagai bangsa Indonesia. Sehubungan konteks keberagaman Indonesia, maka ada beberapa signifikansi dari makna tubuh Kristus yang menjadi pokok-pokok penting bagi gereja untuk memproklamasikan kesaksiannya sebagai garam dan terang. 


\section{Panggilan Memelihara Kesatuan dan Keutuhan}

Dengan salib-Nya orang percaya telah diperdamaikan dengan Allah, disatukan dengan Allah, tanpa memandang orang Yahudi atau orang Yunani atau orang Romawi. Karya pendamaian itu telah meruntuhkan tembok penyekat. Paulus juga dengan tegas dan keras menegur jemaat di Korintus yang menggolongkan diri sebagai golongan Paulus, Apolos dan Kefas. Ia menegur dan mengajar mereka kembali, karena pada kenyataannya mereka adalah satu tubuh. Hal inilah yang menunjukkan keindahan dari Kitab Korintus, dimana Paulus mengajar dan menuntun kembali jemaat di Korintus dengan memandang kepada tubuh Kristus yang telah dikorbankan dan bangkit, dan tubuh-Nya tidak pernah terbagi-bagi.

Adalah providensi Allah, jika gereja bertumbuh dan merambat di bumi Bhineka Tunggal Ika. Hal ini sesungguhnya dapat menjadi bahan refleksi bagi gereja-gereja, untuk tidak tenggelam dalam ketidakmampuan menyatakan kebersatuan dalam keberagamannya. Orang percaya yang telah menerima rekonsiliasi dan menerima pendamaian (atonement) dijadikan satu dengan Allah. Bukan bicara individu semata, tetapi juga orang percaya yang telah disatukan dengan Allah. Pendamaian yang berlaku antar orang percaya dan Allah, juga berlaku atas relasi sesama orang yang telah disatukan. Dengan demikian orang percaya, dapat hidup dalam kesatuan karena ada pendamaian dari Allah, yang harus berlaku atas orang percaya. Demikianlah pendamaian dapat mewujudkan kesatuan.

Gereja hidup dalam konteks Indonesia, ditempatkan untuk menjadi garam dan terang. Berbagai karunia diberikan Tuhan untuk anggota-anggota tubuh Kristus untuk memperlengkapi orang percaya, guna membawa pertumbuhan dan kedewasaan iman jemaat Tuhan. Jika kita mengaku gereja yang kudus dan am, satu ikatan dalam Roh Kudus, bagian gereja sejati yang tak terlihat, maka seharusnya sesama anggota dapat saling bergandengan tangan. Jika tangan kanan berfungsi sebagaimana adanya, maka tangan kiri tidak dapat memprotes segala keberadaan dan hakekat dari tangan kanan. Keduanya tak diperkenankan saling cemburu dan merasa yang paling benar. Keduanya berfungsi masing-masing, dan sang tuan pemilik tangan yang berotoritas memfungsikan keduanya. Hal yang mendasar adalah gerakan 
kerja sama ada diantara keduanya, sehingga harmoni "Supaya mereka menjadi satu", demikianlah seruan doa Yesus, Sang Pendamai, dapat ditemukan diantara mereka. Rasul Paulus juga menyerukan agar "jangan ada perpecahan" (I Kor. 12:12-31), karena penggolongan diri justru menunjukkan ketidakdewasaan, bahkan dengan keras Paulus mengecamnya sebagai manusia duniawi.

Kesatuan internal adalah kesatuan yang tak dapat diganggu gugat oleh siapapun, karena gereja adalah orang-orang-Nya dan bukan gedung-Nya. Dalam sakramen Perjamuan Kudus diperlihatkan akan persatuan orang percaya satu dengan lainnya, sebagai anggota tubuh Kristus yang membentuk suatu kesatuan rohani. ${ }^{27}$ Jika kita mendengar doa Yesus "supaya mereka menjadi satu", juga semestinya dipahami sebagai kesatuan yang terbuktikan dalam kehidupan yang nampak. Kesatuan yang terlihat tidak selalu harus dimengerti sebagai bentuk keseragaman, tetapi keberagaman dalam kesatuan.

Jika mensyaratkan bahwa kesatuan institusional sebagai prasyarat yang harus terpenuhi demi terwujudnya kesaksian gereja sebagai garam dan terang dunia, maka kesatuan institusional bukanlah jawaban, kunci dan fondasi untuk menyatakan gereja dapat disebut sebagai garam di bumi dan terang di dunia. ${ }^{28}$ Memanifestasikan keberadaan dalam panggilan di dunia, dapat diwujudkan dalam kesatuan gereja dengan membangun bentuk kerjasama dalam berbagai program misi dan pelayanan serta bukan semata suatu pertemuan interdenominasional semata. ${ }^{29}$

Keperbedaan pasti akan selalu ada, namun keperbedaan itu semestinya menjadi sarana pertumbuhan dan kedewasaan demi menjadi garam dan terang di negeri tercinta ini. Keberagaman dapat menebarkan nilai keindahan, jika dirangkai dalam dalam kesatuan. Karena adanya keberagaman, maka gagasan kesatuan muncul. Dengan melihat kembali keberagaman denominasi gereja, banyaknya sekolah teologi dan lembaga pelayanan Kristen; tubuh

${ }^{27}$ Berkhof, Teologi Sistematika 5, 188.

${ }^{28}$ Bdk. Phillippe Theron, "One Savior, One Church Reconciliation as Justification and "New Creation" dalam Studies in Reformed Theology, Volume 18: Unity of the Church: A Theological State of the art and Beyond, ed. Van der Borght, E. (Brill Academic Publishers, 2010), 281. Di akses tanggal 18 Februari 2015 di http://ezproxy. library.uph.edu:2130/ lib/pelitaharapan.

${ }^{29}$ Mark Shaw, Sepuluh Pemikiran Besar Dalam Gereja (Surabaya: Penerbit Momentum, 2003), 88 . 
Kristus di bumi pertiwi ini harus lebih memperkokoh panggilan untuk memelihara kesatuan dan keutuhan. Dengan kebesaran hati, gereja dan lembaga-lembaga pelayanan mestinya terlibat dalam karya bersama, yang disertai dengan kerelaan mau belajar, dan kebersediaan menerima satu dengan lainnya. Seperti yang didengungkan dalam hasil Konas PGI 2012 agar gereja-gereja menegaskan komitmennya terhadap sikap saling menerima dan saling menghargai. Hal ini mengacu pada Piagam Saling Mengakui dan Saling Menerima (PSMSM). Dimana gereja-gereja semestinya meningkatkan kerjasama melampaui sekat-sekat doktrinal dan institusi gereja, mengembangkan visi bersama dan saling berbagi sumber daya dan informasi pelayanan. ${ }^{30}$ Kendati ini merupakan hasil dari Konas PGI, namun ini merupakan prinsip pembelajaran yang sangat baik bagi gereja-gereja untuk memelihara kesatuan dan keutuhan.

\section{Panggilan untuk Saling Melengkapi}

Kelahiran beragamnya denominasi tentunya telah juga menjadi embrio bagi lahirnya perkumpulan-perkumpulan gereja di Indonesia, diantaranya PGI, PGLII, PGTI, dan PGPI. Selain itu juga sudah dibentuk perkumpulan regional dan lokal misalnya Badan Kerja Sama Antar Gereja (BKSAG) dan Forum Komunikasi Umat Kristiani (FKUK), baik secara nasional juga regional. Dengan terbentuknya persekutuan-persekutuan baik dalam aras nasional maupun regional, tentunya harapannya adalah meningkatnya komunikasi, relasi dan kerjasama gereja-gereja Tuhan dalam merealisasikan pelayanan di Indonesia. Pelayanan-pelayanan tersebut tentunya sudah banyak memberikan sumbangsih dalam kehadirannya, namun seringkali masih sporadis. Konas 2012 yang digagas oleh PGI mengakui bahwa ekspektasi ini seringkali diperhadapkan dengan tantangan-tantangan internal sehingga menghambat kerjasama antar gereja. Bahkan lebih jauh Konas ini menyoroti bahwa persekutuan yang dibangun dalam harapan kerjasama telah kehilangan

\footnotetext{
${ }^{30}$ Lih. Hasil Konas Misi 2012 yang diselenggarakan oleh WCRC, WCC dan PGI di Jakarta 6-9 Mei 2012. Diakses di http://pgi.or.id/dokumen/hasil-konas-misi-2012 pada tanggal 30 Januari 2015.
} 
akar ditingkat lokal. ${ }^{31}$ Dengan demikian nampaklah bahwa perkumpulan gereja-gereja lokal seringkali hanya sebagai ajang pertemuan saja, tetapi kurang menghidupi visi yang jelas untuk menyatakan kesaksiannya di tingkat lokal dan nasional. Persekutuan gereja-gereja tersebut sudah ada, tetapi optimalitas dari dinamika pelayanan perkumpulan tersebut perlu lebih diperhatikan untuk meningkatkan keaktifan berpartisipasi.

Jika kita kembali melihat dalam jemaat-jemaat, Tuhan sudah memberikan karunia-karunia untuk saling memperlengkapi. Dengan menilik kehidupan gereja dalam pengajaran dan praktek masa kini, bukankah kita harus jujur bahwa kita menemukan jemaat-jemaat lokal yang memiliki keunikan, penekanan, kemampuan yang dapat dikategorikan sebagai karunia yang Tuhan berikan kepada jemaat lokal sebagai anggota tubuh Kristus. Ada gereja yang sangat kuat dalam pengajaran (doktrinal), gereja yang sangat berhasil dalam penggembalaan, gereja yang sangat menonjol dalam pelayanan penginjilan, dan tentunya masih banyak yang dapat kita temukan, yang menjadi keberhasilan pelayanan yang diberkati Tuhan dalam jemaat-jemaat lokal. Jika tiap-tiap anggota jemaat, diberikan karunia untuk saling melengkapi dalam satu jemaat lokal; bukankah tiap-tiap jemaat lokal juga diberikan karunia, yang merupakan panggilan untuk saling melengkapi dalam kesatuan persekutuan jemaat-jemaat Tuhan yang melampaui denominasi, baik ditingkat lokal maupun nasional.

\section{Mewujudkan Unity in Diversity dalam Konteks Bhineka Tunggal Ika}

Memaknai kesatuan gereja sebagai segala sesuatunya satu justru menempatkan kesatuan itu sendiri dalam kekakuan. Kesatuan dengan melihat sebagai keseragaman bukanlah satu syarat bagi gereja untuk dapat menjadi kesaksian bagi dunia, tetapi hidup (life-style) kekeristenan yang menunjukkan kesatuan dalam keberagaman yang dapat menunjukkan kesaksian yang ampuh bagi dunia. Tentunya perlu diwaspadai seperti apa yang telah diingatkan Paulus bahwa peperangan kita bukanlah peperangan kasat mata, tetapi melawan roh-roh di udara, yang dengan segala tipu muslihat akan menyusup dalam

\footnotetext{
${ }^{31}$ http://pgi.or.id/dokumen/hasil-konas-misi-2012; Internet; diakses pada 30 Januari 2015.
} 
kehidupan orang percaya. Berusaha sedemikian rupa untuk memporakporandakan kesatuan anak-anak Tuhan, menjadikan segala halangan rintangan untuk menghadang kejayaan kesaksian Injil. Perpecahan dalam gereja yang diidentifikasi sebagai pengaruh dosa, namun juga dapat menjadi cara musuh Allah untuk menyebabkannya.

Di sisi lain, fanatisme atau arogansi gereja terhadap ajaran atau aliran tertentu, dapat memperparah jalinan relasi antar denominasi gereja. Gereja memiliki dogma, ini benar dan harus. Gereja memiliki kerangka teologi, ini benar dan harus. Tetapi sikap arogansi dan fanatisme berlebihan tentunya tidak dapat dibenarkan, dan diharuskan untuk dihapuskan. Kebersamaan tidak selalu harus meniadakan identitas, tetapi justru kebersamaan harus tetap menampilkan jati diri, sehingga betul-betul nampak keberagaman untuk menciptakan kebersatuan. Perbedaan yang kecil, non esensial dan sekunder tentunya tidak perlu untuk dipoles sehingga menjadi jurang pemisah dalam usaha membangun kebersamaan gereja-gereja Tuhan. Gereja juga harus menyadari bahwa sesama jemaat gereja Tuhan yang berbeda denominasi mungkin akan bertemu di ruang kerja yang sama, di satu institusi yang sama, dalam pertemuan masyarakat, atau dalam lokasi wilayah tempat tinggal masing-masing. Jika gereja menanamkan arogansi dan fanatisme, maka tanpa disadari gereja sudah mengajarkan "ketidakbersatuan" dengan jemaat, dan menanamkan benih kebencian atas denominasi lainnya. Prinsip-prinsip kebenaran yang didasarkan atas kesatuan didalam Kristus harus diberikan dan ditanamkan, sehingga tercipta pribadi-pribadi yang penuh kerendahan hati, memiliki penerimaan yang penuh kasih terhadap sesama anggota tubuh Kristus (walau denominasi gereja berbeda), dan tidak mencela atau mengolok-olok sesama anggota tubuh Kristus, apalagi "merasa" diri yang paling benar.

Tubuh Kristus (baca: gereja) telah ditebus oleh tubuh yang Satu, yaitu Kristus Yesus. Haruslah dengan rendah hati kita mengakui bahwa tidak ada gereja yang sempurna, karena yang sempurna hanyalah gereja jaya, gereja ideal, gereja yang akan datang. Dengan kesediaan mengoreksi diri mungkin dapat menciptakan kebersamaan dan kebersatuan yang lebih erat untuk dapat menjadi saksi bahwa tubuh Kristus sudah dikorbankan, dan tubuh Kristus 
adalah pengharapan yang memberikan jaminan kekal, sehingga prinsip unity in diversity dapat terwujud nyata di bumi Bhineka Tunggal Ika.

\section{PENUTUP}

Dalam keperbedaan, kita adalah jemaat hasil karya pengorbanan tubuh Kristus yang memiliki pengharapan kepada buah sulung dari tubuh kebangkitan Yesus. Karya salib Kristus itulah yang menjadi dasar dan janji di masa yang akan datang, sehingga menjadi pengharapan semua orang percaya. Sebagai tubuh Kristus, kita memiliki satu fondasi dan satu tujuan dan satu kebersamaan dalam keberagaman.

Semoga, jika para pemimpin gereja di bumi Bhineka Tunggal Ika, berkenan memandang kepada salib Kristus yang memancarkan kerendahan hati, ketaatan, kerelaan, tidak mementingkan diri sendiri; memandang salib sebagai satu sumber kehidupan yang sama dari orang percaya; dan mendahulukan kepentingan bersama, menyangkal diri, bahu membahu, sehati sepikir; --mungkin-- gereja Tuhan di tanah air tercinta ini dapat lebih mewujudkan eksistensinya dalam pemberitaan Injil keselamatan dan mewartakan damai sejahtera. Bergandeng tangan menggerakkan jemaat, terlibat aktif dalam peran kesatuan gereja-gereja untuk bersama-sama mengentaskan kemiskinan, mewujudkan lingkungan hidup yang ideal, mencerdaskan anak-anak bangsa, dan masih banyak lagi pekerjaan rumah untuk gereja yang mau bersatu. Sehingga fungsi gereja sebagai garam dan terang dunia dapat terwujud. Meniadakan segala bentuk celaan dan cemoohan. Dengan demikian prinsip unity in diversity dapat terwujud nyata di bumi Bhineka Tunggal Ika, dan nama-Nya dipermuliakan.

Seandainya para pemimpin sama seperti hamba yang memukul-mukul dada mengakui akan keberdosaan, kelemahan dan kepapaan, memohon belas kasihan Tuhan; bukan seperti sang hamba yang dengan bangga mengagung-agungkan diri karena ketekunannya kepada hukum Taurat, tetapi justru menunjukkan kepongahan, dan kesombongan dihadapan Allah; mungkin perpecahan dapat dicegah, perseteruan dapat dihentikan, dan perselisihan berakhir dalam rekonsiliasi. Sehingga kebersamaan sebagai 
communio sanctorum dapat menciptakan satu kehidupan untuk saling berbagi dan melayani.

Ku tak pandang dari gereja mana

Asal kau berdiri atas firman-Nya

Kalau hatimu s'perti hatiku

Kaulah saudara dan saudariku

Ku tak pandang dari gereja mana

Asal kau berdiri atas kalvari

Kalau hatimu s'perti hatiku

Kaulah saudara dan saudariku. ${ }^{32}$

\section{DAFTAR PUSTAKA}

Aritonang, Jan S. Berbagai Aliran di Dalam dan Sekitar Gereja. Jakarta: BPK Gunung Mulia, 2005. . Sejarah Perjumpaan Kristen dan Islam di Indonesia. Jakarta: BPK Gunung Mulia, 2004.

Berkhof, Louis. Teologi Sistematika 3: Doktrin Kristus. Jakarta: Lembaga Reformed Injili Indonesia, 1997. - Teologi Sistematika 5: Doktrin Gereja. Jakarta: Lembaga Reformed Injili Indonesia, 1997.

Borght, van der. Studies in Reformed Theology, Volume 18: Unity of the Church: A Theological State of the Art and Beyond. Leiden: Brill Academic Publishers, 2010.

Fernando, Ajith. Supremasi Kristus. Surabaya: Penerbit Momentum, 2006.

Grenz, Stanley J. Theology For The Community Of God. Grand Rapids:

William B. Eerdmans Publishing Company, 1994.

Grudem, Wayne. Systematic Theology: An Introduction to Biblical Doctrine. Nottingham: Inter-Varsity Press, 1994.

\footnotetext{
${ }^{32}$ Pujian sederhana ini sudah mendengungkan sebuah kesatuan dalam keberagaman dengan memandang kepada yang Satu, yaitu firman dan kalvari. Sungguh memiluan mengingat pujian ini biasa diajarkan dan dinyanyikan oleh anak-anak Sekolah Minggu, namun seringkali dilupakan penghayatannya oleh para pemimpin gereja.
} 
Hoekema, Anthony A. Alkitab dan Akhir Zaman. Surabaya: Penerbit Momentum, 2004.

Morris, Leon. The Apostolic Preaching of the Cross. Grand Rapids: WM. B. Eerdmans Publishing Co., 2000.

Shaw, Mark. Sepuluh Pemikiran Besar Dalam Gereja. Surabaya: Penerbit Momentum, 2003.

Stibbs, A. M. The Meaning of The Word 'Blood' in Scripture. London: The Tyndale Press, 1962.

Stott, John. Kristus Yang Tiada Tara. Surabaya: Momentum Christian Literature, 2007. . The Living Church. Jakarta: BPK Gunung Mulia, 2007.

Wijaya, Yahya. Meniti Kalam Kerukunan. Jakarta: BPK Gunung Mulia, 2007.

http://pgi.or.id/dokumen/hasil-konas-misi-2012.

http://www.gordonconwell.edu/resources/documents/IBMR2015.pdf diakses 18 Februari 2015.

http://www.seabs.ac.id/journal/april2009/500\%20Tahun\%20Yohanes\%20Cal vin.pdf diakses 18 Februari 2015. 